\title{
Ximelagatran was not inferior to warfarin for preventing stroke and systemic embolism in non-valvular atrial fibrillation
}

Executive Steering Committee for the SPORTIF V Investigators. Ximelagatran vs warfarin for stroke prevention in patients with nonvalvular atrial fibrillation: a randomized trial. JAMA 2005;293:690-8.

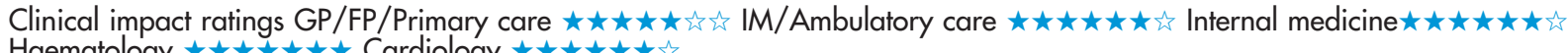

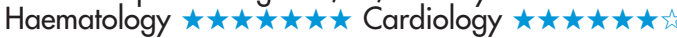

In patients with non-valvular atrial fibrillation requiring long term oral anticoagulant therapy, is fixed dose oral ximelagatran non-inferior to adjusted dose warfarin for preventing stroke and systemic embolism?

\section{METHODS}

Design: randomised controlled trial (Stroke Prevention using an Oral Thrombin Inhibitor in Atrial Fibrillation [SPORTIF] V).

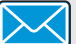

Allocation: concealed.*

Blinding: blinded (clinicians, patients, and outcome assessors).*

Follow-up period: mean 20 months.

Setting: 409 sites in the US and Canada.

Patients: 3922 patients (mean age $72 y, 69 \%$ men) who had persistent or paroxysmal non-valvular atrial fibrillation and $\geqslant 1$ risk factor for stroke (eg, previous stroke, transient ischaemic attack, or systemic embolism; hypertension; left ventricular dysfunction; and age $\geqslant 75 y$ or $\geqslant 65 y$ with coronary disease or diabetes mellitus).

$\mathbf{R}_{\mathbf{X}}$

Intervention: fixed dose oral ximelagatran, $36 \mathrm{mg}$ twice daily $(n=1960)$, or adjusted dose warfarin (target international normalised ratio $2.0-3.0)(n=1962)$

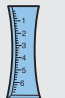

Outcomes: composite endpoint of stroke (ischaemic and haemorrhagic) or systemic embolism. Secondary outcomes included major bleeding, major and minor bleeding combined, myocardial infarction, and elevated liver enzymes (serum alanine aminotransferase concentration $>3$ times the upper limit of normal).

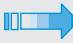

Patient follow up: 100\% (intention to treat analysis)

*See glossary

\section{MAIN RESULTS}

Ximelagatran was non-inferior to warfarin for preventing the composite endpoint of stroke or systemic embolism (table). The groups did not differ for rates of myocardial infarction and major bleeding (table). However, the rate of major and minor bleeding combined was lower in the ximelagatran group than in the warfarin group (table), and more patients in the ximelagatran group had elevated liver enzymes $(6.0 \% v 0.8 \%, \mathrm{p}<0.001)$

\section{CONCLUSION}

In patients with non-valvular atrial fibrillation requiring long-term oral anticoagulant therapy, fixed dose oral ximelagatran was noninferior to adjusted dose warfarin for preventing stroke and systemic embolism.

Abstract and commentary also appear in ACP Journal Club. For correspondence: Dr J L Halperin, Mount Sinai Medical Center, New York, NY, USA; jonathan.halperin@msnyuhealth.org

Source of funding: Astra-Zeneca.
Fixed dose oral ximelagatran (Xim) $v$ adjusted dose warfarin (War) in non-valvular atrial fibrillation requiring long term anticoagulation therapy at mean 20 months*

\begin{tabular}{|c|c|c|c|}
\hline \multirow[b]{2}{*}{ Outcomes } & \multicolumn{2}{|c|}{$\begin{array}{l}\text { Event rate per } \\
\text { patient year }\end{array}$} & \multirow[b]{2}{*}{ Difference $(95 \% \mathrm{Cl})$} \\
\hline & Xim & War & \\
\hline $\begin{array}{l}\text { Any stroke (ischaemic } \\
\text { or haemorrhagic) or } \\
\text { systemic embolism }\end{array}$ & $1.6 \%$ & $1.2 \%$ & $0.45 \%(-0.13$ to 1.0$) \dagger$ \\
\hline Myocardial infarction & $1.0 \%$ & $1.4 \%$ & $-0.4 \%\{-0.9$ to 0.2$\} \pm \S$ \\
\hline $\begin{array}{l}\text { Major bleeding } \\
\text { (excluding extracerebral) }\end{array}$ & $2.4 \%$ & $3.1 \%$ & $-0.66 \%(-1.6$ to 0.23$) \S$ \\
\hline $\begin{array}{l}\text { Major and minor } \\
\text { bleeding combined }\end{array}$ & $37 \%$ & $47 \%$ & $-10 \%(-14$ to -6.0$) \S||$ \\
\hline
\end{tabular}

${ }^{*} \mathrm{Cl}$ defined in glossary. tintention to treat analysis; criterion for noninferiority was met because the upper limit of the $95 \% \mathrm{Cl}$ was $<2 \% /$ year. $\mp \mathrm{Cl}$ provided by author. $\S$ On treatment analysis that discounted events after treatment cessation. I|Significant difference favours xim.

\section{Commentary}

he SPORTIF V trial showed that ximelagatran was non-inferior to warfarin for the prevention of stroke and systemic embolism in patients with non-valvular atrial fibrillation and, compared with warfarin, was associated with a somewhat lower incidence of bleeding. These findings are similar to those from the SPORTIF III trial, which also compared ximelagatran with warfarin therapy in the same patient population. ' Taken together, these studies suggest that ximelagatran is an alternative to warfarin in patients with atrial fibrillation.

Unlike warfarin, ximelagatran is not known to interact with other drugs or foods and has a predictable anticoagulant effect, thereby obviating the need for laboratory monitoring or dose adjustments. It may be speculated that the stable anticoagulation associated with ximelagatran accounts for the lower incidence of bleeding complications compared with warfarin treatment.

Based on these trials, the potential for ximelagatran to replace warfarin for atrial fibrillation is promising but several issues need to be addressed. Firstly, ximelagatran is excreted by the kidneys and patients with a creatinine clearance $<30 \mathrm{ml} / \mathrm{min}$ were not studied. Elderly patients with atrial fibrillation may have unrecognised renal insufficiency, because the serum creatinine concentration does not always reflect renal function. Secondly, the availability of an antidote in case of life threatening bleeding would be desirable, and the options appear limited for ximelagatran. ${ }^{2}$ Finally, $6 \%$ of ximelagatran treated patients developed increased liver enzymes between the $2^{\text {nd }}$ and $6^{\text {th }}$ month of treatment, which has been a consistent finding in all clinical trials so far. It is not clear whether the increase in liver enzymes is associated with a clinically important impairment in liver function, although in virtually all patients the liver enzymes normalised spontaneously or after cessation of ximelagatran. This last issue, especially, requires further study and resolution before ximelagatran can be considered for clinical use. Marcel Levi, MD University of Amsterdam Amsterdam, The Netherlands

1 Olsson SB. Lancet 2003:362:169-8.

2 Wolzt M, Levi M, Sarich TC, et al. Thromb Haemost 2004;91:1090-6. 